\title{
Pharmacogenomic approaches to study the effects of antihypertensive drugs
}

\author{
Kei Kamide ${ }^{1,2}$, Yuhei Kawano ${ }^{3}$ and Hiromi Rakugi ${ }^{1}$ \\ Pharmacogenomic studies aim to clarify the role of various genes and their variations in relation to the effects of \\ antihypertensive drugs to establish a personalized pharmacotherapeutic treatment based on a patient's genetic background. \\ Until recently, there have been numerous pharmacogenetic/pharmacogenomic studies on antihypertensive drugs using \\ candidate genes, but only a few genome-wide approaches have been completed. In this review article, we discuss current \\ trends and future directions of pharmacogenomic studies on antihypertensive drugs. \\ Hypertension Research (2012) 35, 796-799; doi:10.1038/hr.2012.82; published online 28 June 2012
}

Keywords: antihypertensive drugs; candidate genes; GWAS; pharmacogenomics; tailored medicine

\section{INTRODUCTION}

Hypertension is the most common risk factor for atherosclerotic cardiovascular diseases, and its morbidity is greater than $50 \%$ in subjects aged 65 years and older in Japan and most Western countries. In Japan, the number of patients with hypertension is estimated to be greater than 40 million. ${ }^{1}$ Hypertension is a multifactorial disease in which genetic and environmental factors are closely related. Specifically, genetic factors can influence blood pressure elevation by $30-50 \% .^{2}$ Thus, over the last decade, many genetic studies have aimed to clarify the causal genes of hypertension, as reviewed previously. ${ }^{3}$ Genetic research on hypertension started using the candidate gene approach by investigating renin-angiotensin system (RAS)-related genes. ${ }^{4-6}$ Recently, several large-scale genome-wide association studies (GWASs) for hypertension ${ }^{7-9}$ were performed, and $\sim 50$ single nucleotide polymorphisms (SNPs) were identified as possible causal genes.

The goal of genetic studies on hypertension is mainly to clarify the causal genes of hypertension and the mechanisms of blood pressure elevation. Consequently, these approaches may lead to the production of novel antihypertensive drugs. Another important aim is to establish personalized pharmacotherapy based on genetic information. These were the two main aims of the Japanese Millennium Project for Hypertension. ${ }^{10}$ As mentioned, the first aim may be reasonably addressed by large-scale GWAS, but the second aim has not yet been examined in the field of hypertension research.

Recent studies indicate that the heterogeneity of patients' responses to antihypertensive treatment is, at least in part, genetically determined. ${ }^{11}$ This finding underscores the role of pharmacogenetic/ pharmacogenomic research in identifying either functional genetic variations or those variations inherited by linkage disequili- brium. These variations may serve as markers to provide a more individualized evaluation and selection of agents from different drug classes to treat hypertension. ${ }^{12}$ In this review article, we discuss current trends and future directions of pharmacogenomic studies on antihypertensive drugs.

\section{CURRENT TRENDS IN PHARMACOGENETIC/ PHARMACOGENOMIC STUDIES OF HYPERTENSION}

Polymorphisms of genes involved in the RAS, such as ACE $\mathrm{I} / \mathrm{D}^{6}$ polymorphisms and $A G T$ M $235 \mathrm{~T}^{5}$ polymorphisms, were discovered to be associated with high blood pressure nearly 20 years ago. These studies investigated the association of RAS gene polymorphisms and responses to antihypertensive drugs, including angiotensin I-converting enzyme inhibitors (ACEIs), ${ }^{13}$ angiotensin II receptor blockers (ARBs) ${ }^{14}$ beta blockers ${ }^{15}$ and diuretics. ${ }^{16}$ Our group also endeavored to clarify the susceptible gene polymorphisms to thiazide diuretics ${ }^{17}$ and calcium channel blockers $(\mathrm{CCBs})^{18}$ by candidate genes approaches, although there are very limited reports about gene polymorphisms associated with the effects of CCBs. We clarified the associations between CACNA1D rs312481G $>\mathrm{A}$ and rs3774426C $>$ T, and CACNA1C 527974G $>\mathrm{A}$ and treatment with a more significant reduction in $\mathrm{BP}$ for the combined presence of the $\mathrm{L}$ type of CCB's antihypertensive effect in this paper. ${ }^{18}$

In the Japanese Millennium Genome Project, we identified a strong candidate gene, regulator of G-protein-coupled receptor (GPCR) signaling 2 (RGS2), associated with human hypertension ${ }^{19,20}$ and the efficacies of antihypertensive drugs. ${ }^{21}$ RGS2 is a molecule that has a key role in GPCR signaling, including activation of the angiotensin II type 1 receptor. The RGS2-knockout mouse is characterized by a high blood pressure phenotype that is hyper-responsive to ARB

${ }^{1}$ Department of Geriatric Medicine and Nephrology, Osaka University Graduate School of Medicine, Suita, Japan; ${ }^{2}$ Research Institute, National Cerebral and Cardiovascular Research Center, Suita, Japan and ${ }^{3}$ Division of Hypertension and Nephrology, National Cerebral and Cardiovascular Research Center, Suita, Japan 
therapy. ${ }^{22}$ We investigated the correlation between genetic mutations and polymorphisms in RGS2 and human hypertension. We found that rare mutations and common polymorphisms in RGS2 were associated with hypertension in Japanese ${ }^{19}$ and African American patients. $^{23}$ Furthermore, we indicated that a SNP in RGS2 could increase responsiveness to the antihypertensive effects of ACEIs and CCBs. $^{21}$ Taken together, we consider that genetic variations in RGS2 could be new pharmacogenomic targets for some antihypertensive drugs.

However, results from these early pharmacogenetic studies using candidate gene approaches that focused on RAS-related genes or other genes related to blood pressure (BP) regulation are inconsistent. Harrap et al. ${ }^{24}$ indicated that $A C E$ I/D polymorphisms were not associated with stroke onset or ACEI efficacy in a subanalysis of the randomized control trial, The Perindopril pROtection aGainst REcurrent Stroke Study (PROGRESS) In 2005, Arnett et al. ${ }^{25}$ reported the first results from the GenHAT study, which was a large-scale genetic analysis of participants in the Antihypertensive and Lipid-Lowering Treatment to Prevent Heart Attack Trial (ALLHAT) study, a randomized clinical trial that examined the protective effects of four antihypertensive drugs against cardiovascular events. From this report, ${ }^{25}$ ACE I/D polymorphisms genotyped in $\sim 38000$ subjects were found to be unassociated with any cardiovascular event and increased responsiveness to ACEIs, thereby confirming Harrap's report. ${ }^{24}$ These results greatly influenced genetic analysis using candidate gene approaches of RAS-related genes. There are several reports on candidate gene polymorphism analyses using the GenHAT data, including vasoactive substance-like natriuretic peptide, ${ }^{26}$ nitric oxide, ${ }^{27}$ matrix metalloproteinase ${ }^{28}$ and coagulation factor polymorphisms. ${ }^{29,30}$ These studies indicate that gene polymorphisms targeted by candidate gene approaches may have a strong influence on the efficacy of antihypertensive and other cardiovascular drugs; however, most of these results have not been replicated. Thus, candidate gene approaches to pharmacogenetics/pharmacogenomics studies for antihypertensive drugs may not be sufficient to identify all relevant gene variations that affect the responsiveness to antihypertensive drugs. Therefore, GWAS for pharmacogenomic studies of antihypertensive drugs is needed. ${ }^{31}$

TARGET GENES RELATED TO PHARMACOKINETIC FUNCTION According to the review article ${ }^{11}$ by Turner et al., most current studies in pharmacogenetics/pharmacogenomics of antihypertensive drugs are using candidate gene approaches to investigate receptors, enzymes and peptides related to physiologic blood pressure regulation, including those involved in the renin-angiotensin and sympathetic nervous systems, as well as those genes that regulate production of vasoactive substances and water-electrolyte metabolism. Other approaches to clarify the gene polymorphisms that increase responsiveness to antihypertensive drugs are to target mutations and polymorphisms in pharmacokinetic enzyme-associated genes. Certainly, the drug metabolism of most current antihypertensive drugs is not via cytochrome P450 (CYP). ${ }^{12}$ However, some $\beta$-blockers, CCBs and ARBs are metabolized by CYP. We focused on polymorphisms in the gene that codes for CYP2C9, which is a partial metabolite of the ARB, losartan. ${ }^{32}$ We resequenced CYP2C9 in 724 Japanese individuals, including 39 hypertensive patients receiving losartan treatment. Of the two novel missense mutations identified, the Arg132Gln variant showed a fivefold lower intrinsic clearance of diclofenac metabolized by CYP2C9 when expressed in a baculovirusinsect cell system, whereas the Arg335Gln variant had no substantial effect on clearance. Several known missense variations were also found, and $\sim 7 \%$ of Japanese participants (53 out of 724 ) carried one of the deleterious alleles $\left(\right.$ CYP $2 C 9^{\star} 3,{ }^{\star} 13,{ }^{\star} 14,{ }^{\star} 30$ and $\left.\operatorname{Arg} 132 \mathrm{Gln}\right)$ as heterozygotes. After 3 months of losartan treatment, systolic blood pressure was unchanged in two patients with the $C Y P 2 C 9^{\star} 1{ }^{\star} 30$ variation, suggesting that they exhibited impaired in vivo CYP2C9 activity. CYP2C9 30 might be associated with a diminished response to the antihypertensive effects of losartan. ${ }^{32,33}$ These rare mutations related to the effects of antihypertensive drugs should be clarified for all antihypertensive drugs.

\section{GENOME-WIDE APPROACHES TO GENE POLYMORPHISMS THAT INCREASE RESPONSIVENESS TO ANTIHYPERTENSIVE DRUGS}

As mentioned above, the results of pharmacogenetic/pharmacogenomic studies using candidate genes to identify gene polymorphisms that increase responsiveness to antihypertensive drugs are largely controversial. Thus, GWAS also had a desirable application in this research field. To the best of our knowledge, there is only a report by Turner et al. ${ }^{34}$ that associated SNPs with the effects of thiazide diuretics using GWAS and the 100K Affymetrix GeneChip microarray system (Affymetrix, Santa Clara, CA, USA). In this report, haplotype trend regression identified a region of chromosome 12q15 in which haplotypes constructed from three successive single-nucleotide polymorphisms (rs317689, rs315135 and rs7297610), in close proximity to lysozyme (LYZ), YEATS domain-containing 4 (YEATS4) and fibroblast growth receptor substrate 2 (FRS2), were significantly associated with the diastolic BP response to thiazide diuretics. These results were replicated in other ethnic sample sets in this study. ${ }^{34}$ Recently, this group reported that expression analysis in thiazide-treated subjects showed significantly different pre-treatment leukocyte YEATS4 expression in the rs7297610 genotype group. ${ }^{35}$ These results support the use of GWAS analyses to identify novel genes influencing antihypertensive drug responses. The same group proposed a new investigation, called the Pharmacogenomic Evaluation of Antihypertensive Responses (PEAR) study, and recruited 800 hypertensive individuals and randomized them to receive atenolol or hydrochlorothiazide. ${ }^{36}$ The results remain unreported.

In Japan, two major pharmacogenomic studies to identify gene polymorphisms related to the effects of antihypertensive drugs were performed. One is the Hypertension Objective Treatment Based on Measurement by Electrical Devices of Blood Pressure (HOMED-BP) Study, which is a large-scale intervention trial using a PROBE design to determine the optimal target BP level on the basis of self-measured BP with an optimal initial dose of antihypertensive medication. ${ }^{37}$ We are also carrying out a substudy of HOMED-BP, called the HOMED-BPGENE study, which is a GWAS to clarify the genetic background of those patients that respond to antihypertensive medications, including ARBs, ACEIs and CCBs. Another pharmacogenomic GWAS in Japan is the GEANE (Gene Evaluation for Antihypertensive Effect of Drugs) study, which is a multicenter trial to examine the response to 3 months of treatment with ARBs, CCBs and thiazide diuretics using a crossover design. These two studies are focusing on SNPs that increase responsiveness to ARBs, CCBs, ACEIs and thiazide diuretics, which are commonly used as first-line drugs in many published hypertension guidelines. ${ }^{1}$ From these two studies, useful genetic information to establish a tailored therapeutic strategy for hypertension based on a patient's genetic information could be obtained.

\section{POSSIBILITIES OF PERSONALIZED MEDICINE USING PHARMACOGENOMIC INFORMATION}

Anticancer drug treatment relying on personalized medicine, which considers a patient's genetic background, is currently under heavy 
investigation. ${ }^{38}$ Recently, there was a recommendation considering two patient polymorphisms, CYP2C9 and VKORC1, and their response to warfarin. ${ }^{39}$ However, tailored medicine for hypertension treatment based on genetic information has not yet been established, although several pharmacogenetic/pharmacogenomic studies have been completed as mentioned in this review. There are several challenges that should be resolved before such tailored medicine can be employed:

1. Gene polymorphisms and mutations strongly associated with the effects of antihypertensive drugs have not determined. Most obtained results from pharmacogenetic/pharmacogenomic studies have not been validated or replicated in other studies.

2. Clinical parameters are not clear in this research field. The measured BP is quite variable due to the conditions of its measurements. Therefore, it is very difficult to judge responders from non-responders for given antihypertensive drugs.

3. Finally, antihypertensive drugs do not have serious or lethal side effects such as those of anticancer drugs or warfarin. Clinicians may not strongly desire personalized medicine for hypertension therapy. Therefore, hypertensive patients are often taking an antihypertensive drug that is less effective than necessary.

The cost of antihypertensive therapies in aging populations has increased steeply, especially in the United States, Japan and other East Asian countries. If personalized medicine for antihypertensive drugs could be established, the cost of antihypertensive drugs may be reduced due to the discontinuation of the use of less effective antihypertensive drugs. Although there are several obstacles in this research field, the effort must be made to establish personalized medicine for antihypertensive treatments to prescribe the most effective drugs to each hypertensive patient.

\section{ACKNOWLEDGEMENTS}

This study was supported in part by grants-in-aid from the Program for Promotion of Fundamental Studies of the National Institute of Biomedical Innovation of Japan (HR:22-2-5) and the Ministry of Education, Culture, Sports, Science and Technology of Japan (KK: 22510211).

1 Ogihara T, Kikuchi K, Matsuoka H, Fujita T, Higaki J, Horiuchi M, Imai Y, Imaizumi T, Ito S, Iwao H, Kario K, Kawano Y, Kim-Mitsuyama S, Kimura G, Matsubara H, Matsuura H, Naruse M, Saito I, Shimada K, Shimamoto K, Suzuki H, Takishita S, Tanahashi N, Tsuchihashi T, Uchiyama M, Ueda S, Ueshima H, Umemura S, Ishimitsu T, Rakugi H, Japanese Society of Hypertension Committee. The Japanese society of hypertension guidelines for the management of hypertension (JSH 2009). Hypertens Res 2009; 32. 3-107.

2 Dominiczak AF, Negrin DC, Clark JS, Brosnan MJ, McBride MW, Alexander MY. Genes and hypertension: from gene mapping in experimental models to vascular gene transfer strategies. Hypertension 2000; 35: 164-172.

3 Katsuya T, Morishita R, Rakugi H, Ogihrara T. Genetic basis of hypertension for the development of tailored medicine. Hypertens Res 2009; 32: 643-648.

4 Higashimori K, Zhao Y, Higaki J, Kamitani A, Katsuya T, Nakura J, Miki T, Mikami H, Ogihara T. Association analysis of a polymorphism of the angiotensin converting enzyme gene with essential hypertension in the Japanese population. Biochem Biophys Res Commun 1993; 191: 399-404.

5 Caulfield M, Lavender P, Farrall M, Munroe P, Lawson M, Turner P, Clark AJ. Linkage of the angiotensinogen gene to essential hypertension. N Engl J Med 1994; 330: 1629-1633.

6 Higaki J, Baba S, Katsuya T, Sato N, Ishikawa K, Mannami T, Ogata J, Ogihara T. Deletion allele of angiotensin-converting enzyme gene increases risk of essential hypertension in Japanese men: the Suita Study. Circulation 2000; 101: 2060-2065.

7 Kato N, Miyata T, Tabara Y, Katsuya T, Yanai K, Hanada H, Kamide K, Nakura J, Kohara K, Takeuchi F, Mano H, Yasunami M, Kimura A, Kita Y, Ueshima H, Nakayama T, Soma M, Hata A, Fujioka A, Kawano Y, Nakao K, Sekine A, Yoshida T, Nakamura Y, Saruta T, Ogihara T, Sugano S, Miki T, Tomoike H. High-density association study and nomination of susceptibility genes for hypertension in the Japanese national project Hum Mol Genet 2008; 17: 617-627.

8 Tabara Y, Kohara K, Kita Y, Hirawa N, Katsuya T, Ohkubo T, Hiura Y, Tajima A, Morisaki T, Miyata T, Nakayama T, Takashima N, Nakura J, Kawamoto R, Takahashi N, Hata A, Soma M, Imai Y, Kokubo Y, Okamura T, Tomoike H, Iwai N, Ogihara T, Inoue I, Tokunaga K, Johnson T, Caulfield M, Munroe P, Umemura S, Ueshima H, Miki T, Global Blood Pressure Genetics Consortium. Common variants in the ATP2B1 gene are associated with susceptibility to hypertension: the Japanese Millennium Genome Project. Hypertension 2010; 56: 973-980.

9 International Consortium for Blood Pressure Genome-Wide Association Studies, Ehret GB, Munroe PB, Rice KM, Bochud M, Johnson AD, Chasman DI, Smith AV, Tobin MD, Verwoert GC, Hwang SJ, Pihur V, Vollenweider P, O'Reilly PF, Amin N, Bragg-Gresham JL, Teumer A, Glazer NL, Launer L, Zhao JH, Aulchenko Y, Heath S, Sõber S, Parsa A, Luan J, Arora P, Dehghan A, Zhang F, Lucas G, Hicks AA, Jackson AU, Peden JF, Tanaka T, Wild SH, Rudan I, IgI W, Milaneschi Y, Parker AN, Fava C, Chambers JC, Fox ER, Kumari M, Go MJ, van der Harst P, Kao WH, Sjögren M, Vinay DG, Alexander M, Tabara Y, Shaw-Hawkins S, Whincup PH, Liu Y, Shi G, Kuusisto J, Tayo B, Seielstad M, Sim X, Nguyen KD, Lehtimäki T, Matullo G, Wu Y, Gaunt TR, Onland-Moret NC, Cooper MN, Platou CG, Org E, Hardy R, Dahgam S, Palmen J, Vitart V, Braund PS, Kuznetsova T, Uiterwaal CS, Adeyemo A, Palmas W, Campbell H, Ludwig B, Tomaszewski M, Tzoulaki I, Palmer NDCARDIoGRAM Consortium, CKDGen Consortium, Kidney Gen Consortium, EchoGen Consortium, CHARGE-HF Consortium, Aspelund T, Garcia M, Chang YP, O'Connell JR, Steinle NI, Grobbee DE, Arking DE, Kardia SL, Morrison AC, Hernandez D, Najjar S, McArdle WL, Hadley D, Brown MJ, Connell JM, Hingorani AD, Day IN, Lawlor DA, Beilby JP, Lawrence RW, Clarke R, Hopewell JC, Ongen H, Dreisbach AW, Li Y, Young JH, Bis JC, Kähönen M, Viikari J, Adair LS, Lee NR, Chen $\mathrm{MH}$, Olden M, Pattaro C, Bolton JA, Köttgen A, Bergmann S, Mooser V, Chaturvedi N, Frayling TM, Islam M, Jafar TH, Erdmann J, Kulkarni SR, Bornstein SR, Grässler J, Groop L, Voight BF, Kettunen J, Howard P, Taylor A, Guarrera S, Ricceri F, Emilsson V, Plump A, Barroso I, Khaw KT, Weder AB, Hunt SC, Sun YV, Bergman RN, Collins FS, Bonnycastle LL, Scott LJ, Stringham HM, Peltonen L, Perola M, Vartiainen E, Brand SM, Staessen JA, Wang TJ, Burton PR, Artigas MS, Dong Y, Snieder H, Wang X, Zhu H, Lohman KK, Rudock ME, Heckbert SR, Smith NL, Wiggins KL, Doumatey A, Shriner D, Veldre G, Viigimaa M, Kinra S, Prabhakaran D, Tripathy V, Langefeld CD, Rosengren A, Thelle DS, Corsi AM, Singleton A, Forrester T, Hilton G, McKenzie CA, Salako T, Iwai N, Kita Y, Ogihara T, Ohkubo T, Okamura T, Ueshima H, Umemura S, Eyheramendy S, Meitinger T, Wichmann HE, Cho YS, Kim HL, Lee JY, Scott J, Sehmi JS, Zhang W, Hedblad B, Nilsson P, Smith GD, Wong A, Narisu N, Stančáková A, Raffel LJ, Yao J, Kathiresan S, O'Donnell CJ, Schwartz SM, Ikram MA, Longstreth Jr WT, Mosley TH, Seshadri S, Shrine NR, Wain LV, Morken MA, Swift AJ, Laitinen J, Prokopenko I, Zitting P, Cooper JA, Humphries SE, Danesh J, Rasheed A, Goel A, Hamsten A, Watkins H, Bakker SJ, van Gilst WH, Janipalli CS, Mani KR, Yajnik CS, Hofman A, Mattace-Raso FU, Oostra BA, Demirkan A, Isaacs A, Rivadeneira F, Lakatta EG, Orru M, Scuteri A, Ala-Korpela M, Kangas AJ, Lyytikäinen LP, Soininen P, Tukiainen T, Würtz P, Ong RT, Dörr M, Kroemer HK, Völker U, Völzke H, Galan P, Hercberg S, Lathrop M, Zelenika D, Deloukas P, Mangino M, Spector TD, Zhai G, Meschia JF, Nalls MA, Sharma P, Terzic J, Kumar MV, Denniff M, Zukowska-Szczechowska E, Wagenknecht LE, Fowkes FG Charchar FJ, Schwarz PE, Hayward C, Guo X, Rotimi C, Bots ML, Brand E, Samani NJ, Polasek O, Talmud PJ, Nyberg F, Kuh D, Laan M, Hveem K, Palmer LJ, van der Schouw YT, Casas JP, Mohlke KL, Vineis P, Raitakari O, Ganesh SK, Wong TY, Tai ES, Cooper RS, Laakso M, Rao DC, Harris TB, Morris RW, Dominiczak AF, Kivimaki M, Marmot MG, Miki T, Saleheen D, Chandak GR, Coresh J, Navis G, Salomaa V, Han BG, Zhu X, Kooner JS, Melander O, Ridker PM, Bandinelli S, Gyllensten UB, Wright AF, Wilson JF, Ferrucci L, Farrall M, Tuomilehto J, Pramstaller PP, Elosua R, Soranzo N, Sijbrands EJ, Altshuler D, Loos RJ, Shuldiner AR, Gieger C, Meneton P, Uitterlinden AG, Wareham NJ, Gudnason V, Rotter JI, Rettig R, Uda M, Strachan DP, Witteman JC, Hartikainen AL, Beckmann JS, Boerwinkle E, Vasan RS, Boehnke M, Larson MG, Järvelin MR, Psaty BM, Abecasis GR, Chakravarti A, Elliott P, van Duijn CM, Newton-Cheh C, Levy D, Caulfield MJ, Johnson T. Genetic variants in novel pathways influence blood pressure and cardiovascular disease risk. Nature 2011; 478: 103-109.

10 Kamide K, Takiuchi S, Miyata T, Hanai S, Kawano Y, Tomoike H. Single nucleotide polymorphisms analysis of hypertension relating to the effect of antihypertensive drugs - Millennium Genome Project at NCVC. Jpn Heart J 2004; 45: S69-S93.

11 Turner ST, Schwartz GL, Chapman AB, Hall WD, Boerwinkle E. Antihypertensive pharmacogenetics: getting the right drug into the right patient. J Hypertension 2001; 19: $1-11$.

12 Johnson JA. Pharmacogenomics of antihypertensive drugs: past, present and future. Pharmacogenomics 2010; 11: 487-491.

13 Narita I, Goto S, Saito N, Song J, Omori K, Kondo D, Sakatsume M, Gejyo F. Angiotensinogen gene variation and renoprotective efficacy of renin-angiotensin system blockade in IgA nephropathy. Kidney Int 2003; 64: 1050-1058.

14 Kurland L, Melhus H, Karlsson J, Kahan T, Malmqvist K, Ohman KP, Nyström F, Hägg A, Lind LSwedish Irbesartan Left Ventricular Hypertrophy Investigation versus Atenolol (SILVHIA) Trial. Angiotensin converting enzyme gene polymorphism predicts blood pressure response to angiotensin II receptor type 1 antagonist treatment in hypertensive patients. J Hypertens 2001; 19: 1783-1787.

15 Filigheddu F, Argiolas G, Degortes S, Zaninello R, Frau F, Pitzoi S, Bulla E, Bulla P, Troffa C, Glorioso N. Haplotypes of the adrenergic system predict the blood pressure response to beta-blockers in women with essential hypertension. Pharmacogenomics 2010; 11: 319-325.

16 Turner ST, Schwartz GL, Chapman AB, Boerwinkle E. C825T polymorphism of the $G$ protein beta(3)-subunit and antihypertensive response to a thiazide diuretic. Hypertension 2001; 37: 739-743. 
17 Matayoshi T, Kamide K, Takiuchi S, Yoshii M, Miwa Y, Takami Y, Tanaka C, Banno M, Horio T, Nakamura S, Nakahama H, Yoshihara F, Inenaga T, Miyata T, Kawano Y. Thiazide-sensitive $\mathrm{Na}+-\mathrm{Cl}$ - cotransporter gene, C1784T, and adrenergic receptor- $\beta 3$ gene, T727C, may be gene polymorphisms susceptible to the antihypertensive effect of thiazide diuretics. Hypertens Res 2004; 27: 821-833.

18 Kamide K, Yang J, Matayoshi T, Takiuchi S, Horio T, Yoshii Y, Miwa Y, Yasuda H, Yoshihara F, Nakamura S, Nakahama H, Miyata T, Kawano Y. Genetic polymorphisms of L-type calcium channel $\alpha 1_{C}$ and $\alpha 1_{D}$ subunit genes are associated with sensitivity to the antihypertensive effects of L-type dihydropyridine calcium-channel blockers. Circ J 2009; 76: 732-740.

19 Yang J, Kamide K, Kokubo Y, Takiuchi S, Tanaka C, Banno M, Miwa Y, Yoshii M, Horio T, Okayama A, Tomoike H, Kawano Y, Miyata T. Genetic variations of regulator of G-protein signaling 2 in hypertensive patients and in the general population. J Hypertens 2005; 23: 1497-1505.

20 Kohara K, Tabara Y, Nakura J, Imai Y, Ohkubo T, Hata A, Soma M, Nakayama T, Umemura S, Hirawa N, Ueshima H, Kita Y, Ogihara T, Katsuya T, Takahashi N, Tokunaga K, Miki T. Identification of hypertension-susceptibility genes and pathways by a systemic multiple candidate gene approach: the millennium genome project for hypertension. Hypertens Res 2008; 32: 203-212.

21 Sugimoto K, Katsuya T, Kamide K, Fujisawa T, Shimaoka I, Ohishi M, Morishita R, Ogihara T, Rakugi H. Promoter polymorphism of RGS2 gene is associated with change of blood pressure in subjects with antihypertensive treatment: the azelnidipine and temocapril in hypertensive patients with type 2 diabetes study. Int J Hypertens 2010: 196307.

22 Heximer SP, Knutsen RH, Sun X, Kaltenbronn KM, Rhee MH, Peng N, Oliveirados-Santos A, Penninger JM, Muslin AJ, Steinberg TH, Wyss JM, Mecham RP, Blumer $\mathrm{KJ}$. Hypertension and prolonged vasoconstrictor signaling in RGS2-deficient mice. J Clin Invest 2003; 111: 445-452.

23 Riddle EL, Rana BK, Murthy KK, Rao F, Eskin E, O'Connor DT, Insel PA. Polymorphisms and haplotypes of the regulator of $\mathrm{G}$ protein signaling-2 gene in normotensives and hypertensives. Hypertension 2006; 47: 415-420.

24 Harrap SB, Tzourio C, Cambien F, Poirier O, Raoux S, Chalmers J, Chapman N, Colman S, Leguennec S, MacMahon S, Neal B, Ohkubo T, Woodward MPROGRESS Collaborative Group. The ACE gene I/D polymorphism is not associated with the blood pressure and cardiovascular benefits of ACE inhibition. Hypertension 2003; 42: 297-303.

25 Arnett DK, Davis BR, Ford CE, Boerwinkle E, Leiendecker-Foster C, Miller MB, Black $\mathrm{H}$, Eckfeldt $\mathrm{JH}$. Pharmacogenetic association of the angiotensin-converting enzyme insertion/deletion polymorphism on blood pressure and cardiovascular risk in relation to antihypertensive treatment: the Genetics of Hypertension-Associated Treatment (GenHAT). Circulation 2005; 111: 3374-3383.

26 Lynch AI, Boerwinkle E, Davis BR, Ford CE, Eckfeldt JH, Catherine Leiendecker-Foster C, Arnett DK. Pharmacogenetic association of the NPPA T2238C genetic variant with cardiovascular disease outcomes in patients with hypertension. JAMA 2008; 299: 296-307.

27 Zhang $X$, Lynch Al, Davis BR, Ford CE, Boerwinkle E, Eckfeldt JH, LeiendeckerFoster C, Arnett DK. Pharmacogenetic association of NOS3 variants with cardio- vascular disease in patients with hypertension: the GenHAT study. PLoS One 2012; 7: e34217.

28 Sherva R, Ford CE, Eckfeldt JH, Davis BR, Boerwinkle E, Arnett DK. Pharmacogenetic effect of the stromelysin (MMP3) polymorphism on stroke risk in relation to antihypertensive treatment: the genetics of hypertension associated treatment study. Stroke 2011; 42: 330-335.

29 Lynch Al, Boerwinkle E, Davis BR, Ford CE, Eckfeldt JH, Leiendecker-Foster C, Arnett DK. Antihypertensive pharmacogenetic effect of fibrinogen-beta variant $-455 \mathrm{G}>\mathrm{A}$ on cardiovascular disease, end-stage renal disease, and mortality: the GenHAT study. Pharmacogenetics genomics 2009; 19: 415-421.

30 Maitland-van der Zee A-H, Peters BJM, Lynch AI, Boerwinkle E, Arnett DK, Cheng S, Davis BR, Leiendecker-Foster C, Ford CE, Eckfeldt JH. The effect of nine common polymorphisms in coagulation factor genes (F2, F5, F7, F12 and F13) on the effectiveness of statins: the GenHAT study. Pharmacogenetics genomics 2009; 19: 338-344.

31 Arnett DK, Claas SA. Pharmacogenetics of antihypertensive treatment: detailing disciplinary dissonance. Pharmacogenomics 2009; 10: 1295-1307.

32 Yin T, Maekawa K, Kamide K, Saito Y, Hanada H, Miyashita K, Kokubo Y, Akaiwa Y, Otsubo R, Nagatsuka K, Otsuki T, Horio T, Takiuchi S, Kawano Y, Minematsu K, Naritomi H, Tomoike T, Sawada J, Miyata T. Genetic variations of CYP2C9 in 724 Japanese individuals and their impacts on the antihypertensive effects of losartan. Hypertens Res 2008; 31: 1549-1557.

33 Maekawa K, Harakawa N, Sugiyama E, Tohkin M, Kim S-R, Kaniwa N, Katori N, Hasegawa R, Yasuda K, Kamide K, Miyata T, Saito Y, Sawada J. Substrate-dependent functional alterations of seven CYP2C9 variants found in Japanese subjects. Drug Metab Dispos 2009; 37: 1895-1903.

34 Turner ST, Bailey KR, Fridley BL, Chapman AB, Schwartz GL, Chai HS, Sicotte H, Kocher JP, Rodin AS, Boerwinkle E. Genomic association analysis suggests chromosome 12 locus influencing antihypertensive response to thiazide diuretic. Hypertension 2008; 52: 359-365.

35 Duarte JD, Turner ST, Tran B, Chapman AB, Bailey KR, Gong Y, Gums JG, Langaee TY, Beitelshees AL, Cooper-Dehoff RM, Boerwinkle E, Johnson JA. Association of chromosome 12 locus with antihypertensive response to hydrochlorothiazide may involve differential YEATS4 expression. Pharmacogenomics $J$ (e-pub ahead of print 21 February 2012; doi:10.1038/tpj.2012.4).

36 Johnson JA, Boerwinkle E, Zineh I, Chapman AB, Bailey K, Cooper-DeHoff RM, Gums J, Curry RW, Gong Y, Beitelshees AL, Schwartz G, Turner ST. Pharmacogenomics of antihypertensive drugs: rationale and design of the Pharmacogenomic Evaluation of Antihypertensive Responses (PEAR) study. Am Heart J 2009; 157: 442-449.

37 Fujiwara T, Matsubara M, Ohkubo T, Imai Y. Study design of HOMED-BP: hypertension objective treatment based on measurement by electrical devices of blood pressure. Clin Exp Hypertens 2003; 25: 143-144.

38 Ciccolini J, Mercier C, Dahan L, André N. Integrating pharmacogenetics into gemcitabine dosing-time for a change? Nat Rev Clin Oncol 2011; 8: 439-444.

39 Johnson JA. Warfarin pharmacogenetics: a rising tide for its clinical value. Circulation 2012; 125: 1964-1966. 